\title{
Organized Derivatives Market and Economical Growth: Relationship and Impact
}

\author{
V. Oliinyk ${ }^{1}$, I. Burdenko ${ }^{2}$, O.Volynets $^{3}$, V. Yatsenko ${ }^{1}$ \\ ${ }^{1}$ Department of Economic Cybernetics, Sumy State University, Sumy, Ukraine \\ ${ }^{2}$ Department of Accounting And Taxation, Sumy State University, Sumy, Ukraine \\ ${ }^{3}$ Department of Accounting and Taxation, Vinnytsia Trade-Economic Institute KNTEU, Vinnytsia, Ukraine
}

\section{Article Info}

Received Jan 25, 2019

\section{Keyword:}

Economic growth

Exchange-traded derivatives

Financial derivatives

Granger causality test

Organized derivatives market

\begin{abstract}
Derivatives have become common instruments for a wide range of users, including financial institutions, companies that manage assets, corporations, hedge funds. These instruments allow for speculative, arbitrage and hedging operations, which defines them as useful instruments to stimulate the growth of the efficiency of financial markets and the real economy. In this article based on 21 macroeconomic and financial indexes of the USA by test of Granger's relation of cause and effect have been investigated influences of the exchange market of derivatives on indicators of economic growth of the USA. In this article is used a large amount of statistical data of time series and variables of macroeconomic and financial indices. The results of a research have confirmed positive correlation and causality of indicators of economic growth from use of exchange derivatives in real economy. It is received for the studied period of 2000-2015 proofs that the exchange market of derivatives of the USA positively influences the economic. The results obtained during the study can be used to substantiate the necessary measures aimed on the development of the derivatives market in Ukraine.
\end{abstract}

\section{Corresponding Author:}

First Author,

Department of Economic Cybernetics, Sumy State University, Sumy, Ukraine

Email: oliynyk.viktor@gmail.com

\section{Introduction}

In an economic theory, it was traditionally considered that the factors of the real economy ensured economic growth and the financial sector only serves the needs of the economy and its role as a growth factor is secondary. In other words, the main sources of economic growth are technological progress, the accumulation of physical and human capitals and the financial sector was not considered an accelerator of economic growth. This view was based on Solow's (1956) study who considered that financial markets and financial intermediaries were only passively united through household accumulation and did not play any role in the process of physical capital cumulation that was considered an inner factor in an economic development in any country in the world.

The first articles that reviewed the relation between the financial sector and economic growth were attempting to show a certain game between them, without any focusing on the causal link between these phenomenas (Gurley and Shaw, 1967). Hereafter, scientists expanded the range of explorations and confirmed the significance of the financial system for economic development. Nowadays financial derivatives market is the largest segment of the financial market. The rapid development of derivatives is connected with the need of priority usage of derivatives to accumulate financial resources on the world capital market, it transfer, hedge and insure against risk. 
The rapid development of the derivatives market has prompted scientists to study the relation between the new segment of the financial market - the derivatives market and economic growth.

Thus, Merton (1992) in the theoretical research considered the economic functions of derivatives markets and considered that exceptional growth in derivatives markets in the world financial system has been the driving force economic efficiency and economic growth. In his view, derivatives can achieve effectiveness by expanding possibilities of transferring risk, reducing operating expanses and lowering the moral hazard associated with informational asymmetry in financial markets (Merton, 1995).

The last researches confirm that interest in definition of correlation of derivatives market growth with economical growth remains relevant and necessary for making decisions on application of such financial instruments and development of financial engineering.

\section{Materials and methods}

By definition derivatives are contracts with which there is an obligation/right for acquisition or sale of basic financial instruments at in advance agreed price in the future and which allow to perform their inherent functions and at the same time answer such signs: their cost directly depends on the price of a basic financial instrument which is a subject of the agreement; replacement of the obligation/right from movement (supply) of a basic financial asset of the obligation/right from movement of the fictitious capital (a prepotent form of the fictitious capital); establish ratios between profitability and risk operations; ratio models between certain rights, duties and responsibility of participants of the legal relationship connected with derivatives (IFRS 9 Financial Instruments).

Hedging of market risks of subjects of housekeeping on commodity, and later the financial markets and also maintenance of liquidity of hedgers was the starting purpose of derivatives creation. At the same time for the period of emergence and development of the derivative market these tools had no global speculative or arbitration character. For a short time of market development of financial derivative instruments since 70th of the 20 centuries speculative operations with derivatives have gained priority value. A main objective of derivative application is their use for management of market risks, hedging, arbitration and speculation. However, for today derivatives carry out not only microeconomic, but also macroeconomic functions (Fig.1).

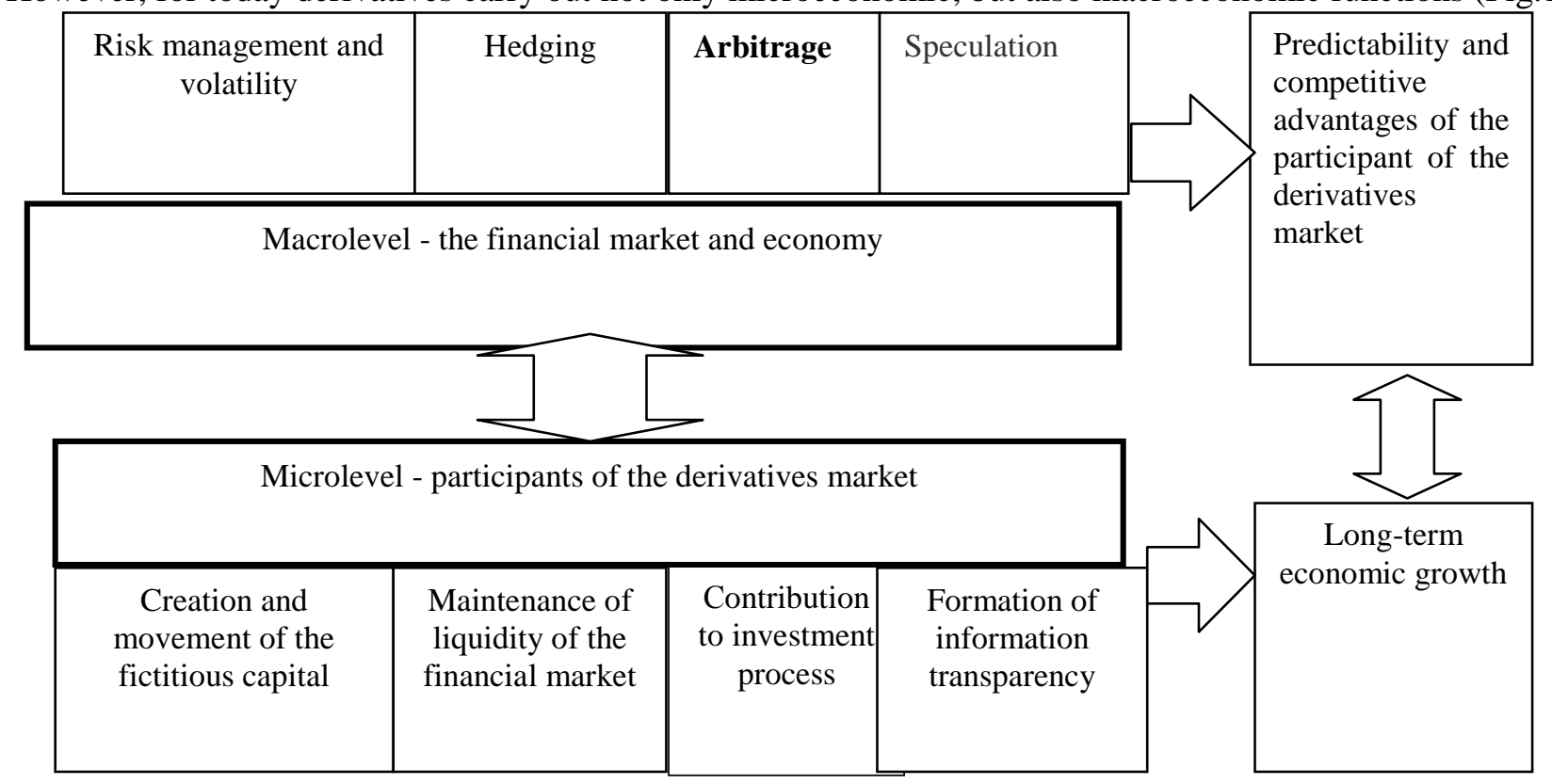

Figure 1. Functions of derivatives market and their interrelation

The derivatives market at the same time is young and considerable segment of the world financial market. The world derivatives market was actually created only in the 70th in the USA and in the 80th of the XX century in Europe and Japan. However, despite of its large volumes of trade and growth rates, there is an impartial relation and mistrust to derivatives as operations with such financial instruments are quite risky and dangerous, and sometimes and provoke the beginning of financial crisis. 
For the correct application and avoidance "derivatives phobia" it is necessary to understand specifics of derivatives and their value for real economy.

During 2000 to 2015, the volume of amounts outstanding of futures in the region of North America was increased from $\$ 4208$ billions to $\$ 15649$ billions (Fig. 1), representing an average annual growth on 9.03\%. The annual volume of amounts outstanding of futures in Europe over the same period increased from \$2,314 billion to $\$ 7040$ billion, with an average annual growth of $7.70 \%$. The rapid growth of volumes of option operations has been observed, and from 2000 to 2015 the volume of option's amounts in North America region increased from $\$ 3829$ billions to $\$ 26735$ billions (Fig. 2), representing an average annual growth of $13.83 \%$. The annual turnover of options in Europe over the same period was increased from $\$ 1,880$ billion to $\$ 11450$ billion, with an average annual growth of $12.80 \%$.

In general, by its scale and growth rates of the world derivatives markets since the beginning of their development in the 70's of XX century are the largest and the most dynamic in relation to other types of markets, despite the fact that in 2008 there was a decline in the volume of amounts outstanding of exchangetraded futures and options in North America by 12565.8 billion dollars, and in Europe by 5948.49 billion dollars. However, in 2009, volumes with exchange-traded derivatives almost reached pre-crisis level. The revival in the world derivative financial instruments traded on organised exchanges was primarily due to the growth derivatives turnover of short-term interest rate, as well as with growth derivatives turnover on the Equity Index. The overall growth of the organized derivatives market in these regions and 15 years amounted to $327 \%$.

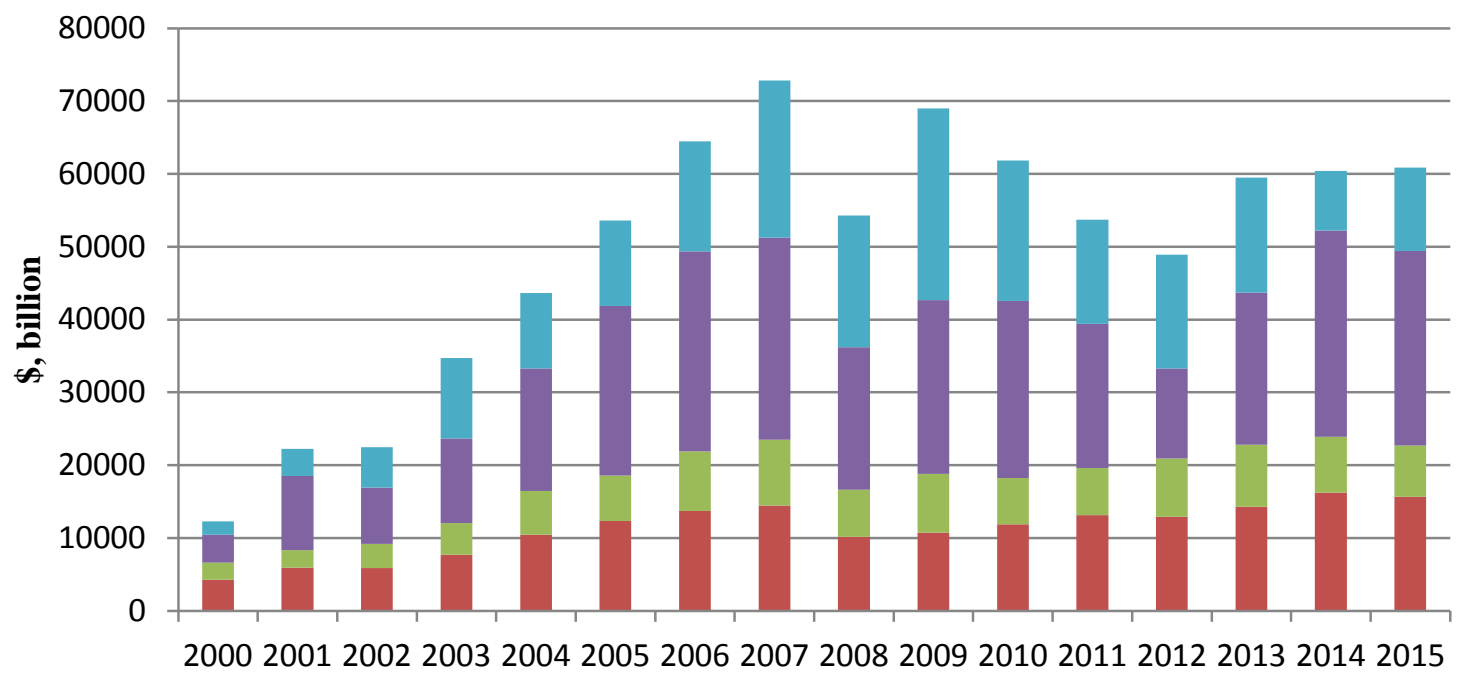

Futures (North America ) - Futures (Europe)

Figure 2. Exchange-traded futures and options Source: Authors' calculations

In summary, implementation of the functions by the derivatives market promotes growth of investment process, maintenance of liquidity of the financial market, provide of information transparency which leads to resistant long-term economic growth.

The founder of the theory of economic development was Schumpeter, who considered that financial intermediaries (banks), through mobilizing funds and monitoring risks, associated with credits and loans, could better control the actions of company's managers than individual separated investors. Particularly this increases the volume of transactions in the economy and promotes technological innovations and economic development. Schumpeter emphasizes that the financial sector is capable to redistributing capital in such a way that it only reaches those hands in which it can bring maximum benefits, which is an important accelerator of growth. The same idea was followed by Hicks (1969) who considered that the main reasons of the industrial revolution in England were the development of the capital market that reduced liquidity risk and mobilized savings with further investing of them. He emphasizes that technological innovations did not affect on the economic growth of the economy.

Hereafter, explorers expanded the range of studies and confirmed the importance of the financial sector for economic growth. Thus, in particular, Romer (1986) presented a new model that showed the prospect of long- 
term economic development. The model has allowed substantiating the assertion that the growth of per head profitability from scale could increase without any obligations, over time, at an increasing pace, as evidenced by the growth of new economies against the backdrop of capital contributions inside and outside the country. Level of financing and return on equity may grow with an increase in whole equity per share, as we deviate from the acceptance of a decrease in profits (Baluch and Ariff, 2007).

King and Levine (1993) have studied whether there is a positive relation between financial development and the level of economic increase. Their conclusion is that components such as development of financial system are a good indicator of long-term growth and that financial development implies predicting (1) the rate of cumulation of physical capital and (2) increasing the efficiency of its distribution.

The optimal control of the GDP indicator from a given initial state (2016) to a given final state (2021) is presented in Oliinyk (2018). The study was conducted for 6 countries: United States, Korea, India, United Kingdom, France and Belgium. The obtained results can be used in modeling and forecasting financial market indicators.

Later studies by Rousseau and Wachtel $(2006,2008)$, based on financial and macroeconomic data from 1960 to 2003, deepened the study of King and Levine and found that the influence of the financial market on economic growth was not so steady. In addition, Rousseau and Wachtel (2009) suggested that the reduction of the financial system's influence on economic growth was due to (1) the frequency of financial crises and (2) the efforts of countries in financial liberalization. They emphasize the negative influence of financial crises on economic growth and have not found evidence that liberalization has led to a weakening link between the financial market and economic growth. They emphasize the role of financial crises and underlying excessive financial deepening in their analysis

Their further research has allowed to check whether the frequency of domestic banking and financial crises affects on the depth of the financial market and economic growth.

They have proved that the depth of the financial market has a strong influence on economic growth throughout the sample period (period 1: 1960 - 1989, period 2: 1990 - 2003), as long as a country can evade the financial crisis. Moreover, they note that during the crisis, the depth of the financial market ceases to affect economic growth. In addition, they have proved that financial liberalization does not reduce the depth of the financial market. However, this did not affect the conclusion that countries with a higher level of development of financial sector tend to have higher rates of economic increase than low-income countries in the financial market.

Development of the financial engineering, merging of stock exchanges, emergence of the internet and improvement of telecommunication technologies have influenced on a formation of the latest structure of the financial markets and its institutes (Merton and Bodie, 2005).

Modern studies deepen knowledge of the new vectors of the financial market's influence on economic growth, in particular, functional and institutional peculiarities of financial architecture. Different scientists have done a research of the influence of additional sectors of the financial market on economic growth, namely the insurance market, both the financial intermediary and the provider of transfer and risk reimbursement (Arena, 2006).

Arena (2006) having applied generalized method of moments (GMM model) to 56 countries during 19762004 proves that between activity of the market of insurance and economic growth there is a strong interrelation (Arena, 2006). The researches of Greenwood and Jovanovic (1990) also finished communication between financial architecture and economic development.

To the extent of a single model, they have proved that economic growth and financial structure are inextricably linked. The growth allowed developing the financial structure, and, in turn, it allowed increasing economic growth. This article presents a model of endogenous growth in which financial intermediaries reduce the risk of investing for investors, as well as finance projects with higher returns and risk.

Another aspect that was considered by Greenwood and Jovanovic (1990) is related with information flows generating the financial market. They considered that the information is valuable to investors as it allows you to know only about the latest production technologies and also contributes to investing in more promising and profitable investment directions.

However, it should be noted that most of the previous explorations reviewed the role of financial intermediaries, namely banks, on the economic growth and only in the late 90s of the twentieth century began to pay attention to the relation of the stock market (Levine and Zervos, 1998) with economic growth. 
1. Thus, they investigating the role of the stock market, namely the equity market for economic growth, according to 42 countries over the period 1976-1993, have concluded that there was a positive correlation between the growth of stock market liquidity and future economic growth.

It can be expected that the development of new asset classes and the change ininstitutional structures can increase the ability of financial sectors to promote economic growth, although financial innovation can also affect the stability of the financial sector (Rajan, 2006).

Favara has reviewed the relation between financial development and economic growth using cross-country analysis. The results indicate that: (1) the external element of progress does not stimulate economic development; and (2) if fast-moving specification and slope heterogeneity throughout the countries are taken into consideration, an approximate effect of financial growth on GDP development is insignificant and, for some compaund of controls and report period. Thus, the relation between finance and growth is quite varied in time and space (Favara, 2009).

The first empirical study that looked at the correspondence between the derivatives market and economic growth was conducted by Tsetsekos and Varangis (2000). The research concerned mostly the inherent parameters of the market architecture of the derivatives market and their institutional mechanism, but they also attempted, using economic and market data for the period 1984-1992, to confirm the level of variability between economic and market states (indicators) between developed economies and an emerging market economy to explain the differences in the development of the derivatives market in these countries. They concluded that it was necessary to develop its exchange segment and instruments for the market to realize its benefits.

He theoretically tried to prove his opinion with demonstration of the latest financial products and their influence on the growth of financial markets and the economy in general.

Baluch and Ariff (2007) continued the exploration of the relation between the development of the derivatives market and economic development. Their research has covered 11 countries, including 5 developed and 6 with emerging economies. The results of the study indicate a small correlation and the influence the derivatives market on economic growth. At the same time, they concluded that there was negative correlation between the level of liquidity of derivatives markets and economic growth in developed countries, indicating a significant contribution of the derivatives market through the transfer of risk on economic growth.

Haiss and Sammer (2010) have analyzed the influence of the derivatives market on the economy through transfer function (volume, efficiency, risk channels). They empirically checked whether the development of the derivatives market was influencing the ability of the financial sector to contribute to economic growth in the United States from the first quarter of 1990 to the 3rd quarter of 2008. Their study was based on the functional approach of Merton and Bodie (1995). In the course of the study, it was concluded that there is only a weak correlation between the financial sector and derivatives in particular, with economic growth.

However, there are studies that justify the availability of feedback. Thus, Lazovy and Sipko (2014), studying the impact of financial derivatives on the real economy for the period 1986-2012, have shown that growth of OTC derivatives market reduces economic growth.

Bujari and Venegas-Martinez (2015) empirically have proved that the increase of the derivatives market activity has a positive influence on economic development for the period 2002-2014. They've emphasized that derivatives market is perspective and directly influences on real economy and its growth. However for elimination of threat of financial crises which the derivatives market can provoke and ensuring transparency of derivatives market, it is necessary to carry out an application of all regulatory actions that the world economy will have the sustainable and balanced development (Bujari and Venegas-Martinez, 2016).

Consequently, the last researches show a productive interrelation between the growth of the derivatives market and economic.

With the deepening of globalization processes, the growth of volumes of fictitious capital embodied in financial derivatives on world markets, the negative influence on a world financial stability, the discussion about the nature and role of these instruments and their markets in the future financial architecture has intensified. We support opinion of Bujari and Venegas - Martinez (2016) that financial derivatives certainly are capable to accelerate development of financial innovations and investments and also provide effective mechanisms of hedging and management of financial risks (Bujari and Venegas-Martinez, 2016).

Analyzing the derivatives market and considering it as an abstract category, separation of its system essence from the inextricable interpenetration of the market - the system of derivatives and the market - the system of basic instruments, as well as between different markets and types of derivatives themselves. Accordingly, when moving to a specific, the financial derivatives market system is open to interact with other systems. The 
derivatives market is a system of third order in relation to the basic assets (tertiary market) and with the development of financial engineering on the derivatives market of the four level system is depositing - the derivatives market on derivative the quaternary market is aligned.

Using derivatives allows obtaining the information about future market prices and courses on basic financial instruments that helps to decide on activity planning by development of business both at the macrolevel and at the microlevel. This derivatives function allows to place more optimum financial resources in the spot market and to increase quality of management decisions. Besides, there are special derivatives on economic indicators which prices act as indicators of future economic expectation of investors concerning development of economy of the countries.

Thus, the development of the derivatives market performed as a guarantee of the efficient functioning of not only the financial market, but also translates its influence on the effective functioning of the real economy. The existence of a dilemma between the role of the financial derivatives market as an instrument of macroeconomic stabilization and its possible destructive influence on the entire financial market necessitates a study of the influence of the derivatives market on an economic growth.

To prove the hypothesis of the effects of the organized derivatives market on an economic growth was used a Granger causality test and 21 macroeconomic and financial indicators of the United States. The empirical analysis is covers the period from 2000 to 2015. The verification of the cause-effect relationship between time series was carried out for four lags. To assess the significance of the model in general, were used Fisher's statistics (F-test, F-statistics). The probability of a hypothesis error was verified by using p-value. To test the time series for stationary, use the Augmented Dickey-Fuller test (ADF-test).

2. For our study, we examined 21 indicators: $X_{1}-$ Annual volume of amounts outstanding of financial derivatives by regions and instruments; $\mathrm{X}_{2}-$ GDP US, USD Billion; $\mathrm{X}_{3}-$ GDP per capita growth, \%; $\mathrm{X}_{4}-$ GDP growth, $\% ; \mathrm{X}_{5}-$ GDP deflator, $\% ; \mathrm{X}_{6}-$ Unemployment rate, $\% ; \mathrm{X}_{7}$ - Inflation, consumer prices, $\% ; \mathrm{X}_{8}-$ Personal income, USD Billion; $\mathrm{X}_{9}-$ Federal funds rate, $\% ; \mathrm{X}_{10}$ - Manufacturing Purchasing Managers Index; $\mathrm{X}_{11}$ - Cash surplus/deficit (\% of GDP); $\mathrm{X}_{12}$ - Gross capital formation (\% of GDP); $\mathrm{X}_{13}$ - Portfolio Investment, net (BoP, current US\$); $\mathrm{X}_{14}-$ Bank capital to assets ratio (\% of GDP); $\mathrm{X}_{15}$ - Real interest rate, \%; $\mathrm{X}_{16}$ Market capitalization of listed domestic companies (current US\$); $\mathrm{X}_{17}$ - Broad money (\% of GDP); $\mathrm{X}_{18}$ Exports of goods and services (\% of GDP); $\mathrm{X}_{19}$ - Personal remittances, received, (current US\$); $\mathrm{X}_{20}-$ Domestic credit to private sector by banks (\% of GDP); $\mathrm{X}_{21}$ - Financial Stress Index.

The information base of the study is the data of the World Bank, The International Monetary Fund (IMF), World Statistics on the main macroeconomic indicators of the USA for 2000-2015, the Bank of International Settlements (BIS) - in terms of transactions with derivatives.

Due to data access restrictions empirical analysis is limited to one country - the United States.

To prove our hypothesis of the influence of the development of the organized derivatives market on economic growth we applied Granger causality test. Granger causality test was used to determine whether the organized derivatives market was the reason for the change level in economic growth.

The essence of Granger causality test is that the variable $x$ is causal in relation to the variable $y$, that is under the influence of $x \rightarrow y$ the changes $x$ should be preceded by changes in $y$, and not vice versa. Consequently, under the above conditions, it is necessary that the following actions be performed simultaneously: the variable $x$ makes a significant contribution to the forecast in $y$, while the variable $y$ does not make a significant contribution to the prediction of the variable $x$.

Two linear regressions are constructed to test the cause-effect relation between time series:

$$
\begin{aligned}
& y_{t}=a_{0}+\sum_{i=1}^{p} a_{i} y_{t-i}+\sum_{i=1}^{p} b_{i} x_{t-i}+\varepsilon_{t} \\
& x_{t}=c_{0}+\sum_{i=1}^{p} c_{i} x_{t-i}+\sum_{i=1}^{p} d_{i} y_{t-i}+u_{t}
\end{aligned}
$$

Checking for causality involves the use of stationary time series. In statistical analysis of time series it is necessary to have stationary time series. To test the time series for stationary, use the Augmented DickeyFuller test (ADF-test).

Check is carried out for three types of the equations:

1. none: $\Delta Y_{t}=d Y_{t-1}+\sum_{i=1}^{p} c_{i} \Delta Y_{t-i}+\varepsilon_{t}$

2. intercept: $\Delta Y_{t}=b_{0}+d Y_{t-1}+\sum_{i=1}^{p} c_{i} \Delta Y_{t-i}+\varepsilon_{t}$

3. trend and intercept: $\Delta Y_{t}=b_{0}+b_{1} t+d Y_{t-1}+\sum_{i=1}^{p} c_{i} \Delta Y_{t-i}+\varepsilon_{t}$ 
where:

$b_{0}, b_{1}, d, c_{i}-$ the parameters of the model; $\Delta Y_{t}=Y_{t}-Y_{t-1}-$ the first differences; $\varepsilon_{t}-$ mistake.

The following hypothesis is tested:

$\mathrm{H}_{0}: d=0$, a time row is non-stationary;

$\mathrm{H}_{1}: d<0$, a time row is stationary.

The null hypothesis of $\mathrm{H}_{0}$ can be rejected if $\mathrm{d}<0$ and for McKinnon's statistics the calculated size p-value is less, than the set significance value of $\alpha$.

\section{Results and discussion}

By results of the check on stationarity of hour ranks of absolute values of macroeconomic indicators for Augmented Dickey - Fuller test (Table 1) was taken a hypothesis of $\mathrm{H}_{0}$ which allows revealing not stationarity of the majority of macroeconomic indicators.

Table 1 ADF unit roots test at level

\begin{tabular}{|c|c|c|c|c|}
\hline \multirow{2}{*}{ № } & \multirow{2}{*}{ Variables } & \multicolumn{3}{|c|}{ Fisher Chi-Square statistic at level } \\
\hline & & None & Intercept & Trend and intercept \\
\hline 1 & $\mathrm{X}_{1}$ & 0.593 & -1.990 & -1.971 \\
\hline 2 & $X_{2}$ & 6.214 & 0.366 & $-4.286^{* *}$ \\
\hline 3 & $\mathrm{X}_{3}$ & $-2.503 * *$ & $-2.883^{*}$ & -2.676 \\
\hline 4 & $X_{4}$ & $-1.928^{*}$ & $-2.937 *$ & -2.716 \\
\hline 5 & $\mathrm{X}_{5}$ & 1.648 & -0.669 & -1.937 \\
\hline 6 & $X_{6}$ & -0.651 & -2.162 & -2.081 \\
\hline 7 & $X_{7}$ & 6.522 & -1.166 & -1.153 \\
\hline 8 & $\mathrm{X}_{8}$ & 6.052 & 0.891 & -2.929 \\
\hline 9 & $\mathrm{X}_{9}$ & $-1.845^{*}$ & -2.543 & $-4.051 * *$ \\
\hline 10 & $\mathrm{X}_{10}$ & -0.347 & $-2.898 *$ & -2.822 \\
\hline 11 & $X_{11}$ & -0.973 & -1.203 & 0.157 \\
\hline 12 & $\mathrm{X}_{12}$ & -0.894 & -1.606 & -3.102 \\
\hline 13 & $\mathrm{X}_{13}$ & -0.714 & $-2.895^{*}$ & $-3.443^{*}$ \\
\hline 14 & $\mathrm{X}_{14}$ & -0.074 & $-2.797 *$ & $-3.769 * *$ \\
\hline 15 & $\mathrm{X}_{15}$ & $-2.391 * *$ & -2.526 & $-3.567 * *$ \\
\hline 16 & $\mathrm{X}_{16}$ & 0.507 & -0.996 & -2.193 \\
\hline 17 & $\mathrm{X}_{17}$ & 1.795 & -0.944 & -1.735 \\
\hline 18 & $\mathrm{X}_{18}$ & 0.441 & -0.846 & -2.805 \\
\hline 19 & $\mathrm{X}_{19}$ & 7.073 & 2.072 & -1.438 \\
\hline 20 & $X_{20}$ & 0.275 & -2.015 & -1.977 \\
\hline 21 & $X_{21}$ & $-2.191 * *$ & -2.241 & -2.725 \\
\hline
\end{tabular}

*.**.*** - Significant at 10\%. 5\%. $1 \%$ critical level

Source: Authors' calculations

Let's notice that stationary were such indicators: $\mathrm{X}_{2}$ is GDP US, the current prices, bln. dollars of the USA; $\mathrm{X}_{3}$ is \% GDP per capita growth; $\mathrm{X}_{9}$ is \% Federal funds rate; $\mathrm{X}_{14}$ is Bank capital to assets ratio (\% of GDP); $\mathrm{X}_{15}$ is Real interest rate (\%). Simultaneously, the main variable of our research $\mathrm{X}_{1}$-The annual volume of amounts outstanding of financial derivatives was non-stationary that made inexpedient application of Granger causality test for absolute sizes of macroeconomic indicators.

For reduction of non-stationary indicators to stationary we used process of capture of the first differences. Results of check of indicators of the first differences showed their stationarity (Table 2).

Table 2. ADF unit roots test at first differences

\begin{tabular}{ccccc}
\hline \multirow{2}{*}{ № } & $\begin{array}{c}\text { Variables } \\
\text { (first } \\
\text { differences) }\end{array}$ & None & Intercept & Trend and intercept \\
\hline 1 & $\Delta \mathrm{X}_{1}$ & $-3.362^{* * *}$ & $-3.434^{* *}$ & -3.320 \\
2 & $\Delta \mathrm{X}_{2}$ & -1.060 & $-3.391^{* *}$ & -3.078 \\
3 & $\Delta \mathrm{X}_{3}$ & $-5.019^{* * *}$ & $-4.815^{* * *}$ & $-4.560^{* *}$ \\
4 & $\Delta \mathrm{X}_{4}$ & $-5.066^{* * *}$ & $-4.853^{* * *}$ & $-4.594^{* *}$
\end{tabular}




\begin{tabular}{llccc}
5 & $\Delta \mathrm{X}_{5}$ & -0.939 & -2.196 & $-3.473 * *$ \\
6 & $\Delta \mathrm{X}_{6}$ & $-2.126^{* *}$ & -2.005 & -2.143 \\
7 & $\Delta \mathrm{X}_{7}$ & -1.398 & $-3.043^{*}$ & -3.120 \\
8 & $\Delta \mathrm{X}_{8}$ & -0.609 & $-3.181^{* *}$ & $-3.154^{*}$ \\
9 & $\Delta \mathrm{X}_{9}$ & $-2.642^{* *}$ & -2.505 & -2.359 \\
10 & $\Delta \mathrm{X}_{10}$ & $-3.150^{* * *}$ & $-2.951^{* *}$ & -2.892 \\
11 & $\Delta \mathrm{X}_{11}$ & -1.494 & -1.339 & -1.881 \\
12 & $\Delta \mathrm{X}_{12}$ & $-2.883^{* * *}$ & $-2.751^{*}$ & -2.625 \\
13 & $\Delta \mathrm{X}_{13}$ & $-8.028^{* * *}$ & $-7.753^{* * *}$ & $-8.100^{* * *}$ \\
14 & $\Delta \mathrm{X}_{14}$ & $-3.309^{* * *}$ & $-3.222^{* *}$ & -3.036 \\
15 & $\Delta \mathrm{X}_{15}$ & $-2.929^{* * *}$ & $-2.823^{*}$ & -2.631 \\
16 & $\Delta \mathrm{X}_{16}$ & $-3.661^{* * *}$ & $-3.726^{* *}$ & $-3.636^{*}$ \\
17 & $\Delta \mathrm{X}_{17}$ & $-3.174^{* * *}$ & $-3.627 * *$ & $-3.479 *$ \\
18 & $\Delta \mathrm{X}_{18}$ & $-3.404^{* * *}$ & $-3.489^{* *}$ & -3.161 \\
19 & $\Delta \mathrm{X}_{19}$ & 0.658 & $-3.269^{* *}$ & $-5.059^{* * *}$ \\
20 & $\Delta \mathrm{X}_{20}$ & $-2.383^{* *}$ & -2.299 & -2.158 \\
21 & $\Delta \mathrm{X}_{21}$ & $-2.745^{* * *}$ & $-2.695^{*}$ & -2.571 \\
$* * * * * *$ & Significant at $10 \%, 5 \% .1 \%$ critical level & & \\
\hline
\end{tabular}

***.*** - Significant at $10 \% .5 \% .1 \%$ critical level

Source: Authors' calculations

Behind results of check on stationarity of hour ranks of the first differences of values of macroeconomic indicators for Augmented Dickey - Fuller test (Table 2) was rejected a hypothesis of $\mathrm{H}_{0}$ which allows to reveal stationarity of the majority of macroeconomic indicators.

In Table 3 results of Granger causality test for four lags are reported.

Table 3. Granger Causality Test

\begin{tabular}{|c|c|c|c|c|c|c|c|c|c|}
\hline \multirow[t]{2}{*}{ № } & \multirow[t]{2}{*}{ Null Hypothesis } & \multicolumn{2}{|c|}{ Lag1 } & \multicolumn{2}{|c|}{ Lag2 } & \multicolumn{2}{|c|}{ Lag3 } & \multicolumn{2}{|c|}{ Lag4 } \\
\hline & & $\begin{array}{c}\text { F- } \\
\text { statistic }\end{array}$ & Prob. & $\begin{array}{c}\text { F- } \\
\text { statistic }\end{array}$ & Prob. & $\begin{array}{c}\text { F- } \\
\text { statist } \\
\text { ic }\end{array}$ & Prob. & $\begin{array}{c}\text { F- } \\
\text { statistic }\end{array}$ & Prob. \\
\hline 1 & $\begin{array}{l}\Delta \mathrm{X}_{1} \text { does not Granger } \\
\text { Cause } \Delta \mathrm{X}_{3}\end{array}$ & 1.604 & 0.231 & 4.306 & $0.053 *$ & 3.720 & $0.095^{*}$ & 26.283 & $0.037 * *$ \\
\hline 2 & $\begin{array}{l}\Delta X_{1} \text { does not Granger } \\
\text { Cause } \Delta X_{4}\end{array}$ & 1.736 & 0.214 & 4.494 & $0.049 * *$ & 3.633 & $0.099 *$ & 33.546 & $0.029 * *$ \\
\hline 3 & $\begin{array}{l}\Delta X_{1} \text { does not Granger } \\
\text { Cause } \Delta X_{6}\end{array}$ & 4.432 & $0.059 *$ & 4.736 & $0.043 * *$ & 6.019 & $0.041 * *$ & 7.906 & 0.115 \\
\hline 4 & $\begin{array}{l}\Delta X_{1} \text { does not Granger } \\
\text { Cause } \Delta X_{8}\end{array}$ & 10.604 & $0.007 * * *$ & 10.058 & $0.006 * * *$ & 6.143 & $0.039 * *$ & 3.700 & 0.223 \\
\hline 5 & $\begin{array}{l}\Delta X_{1} \text { does not Granger } \\
\text { Cause } \Delta X_{10}\end{array}$ & 0.045 & 0.835 & 7.085 & $0.010 * *$ & 5.189 & $0.053 *$ & 1.451 & 0.446 \\
\hline 6 & $\begin{array}{l}\Delta X_{1} \text { does not Granger } \\
\text { Cause } \Delta X_{12}\end{array}$ & 3.920 & $0.073 *$ & 3.919 & $0.065^{*}$ & 3.770 & $0.093 *$ & 47.141 & $0.020 * *$ \\
\hline 7 & $\begin{array}{l}\Delta X_{1} \text { does not Granger } \\
\text { Cause } \Delta X_{13}\end{array}$ & 9.081 & $0.011 * *$ & 3.158 & $0.097 *$ & 4.508 & $0.069 *$ & 3.988 & 0.210 \\
\hline 8 & $\begin{array}{l}\Delta X_{14} \text { does not } \\
\text { Granger Cause } \Delta X_{1}\end{array}$ & 0.053 & 0.821 & 0.271 & 0.768 & 5.419 & $0.049 * *$ & 2.857 & 0.275 \\
\hline 9 & $\begin{array}{l}\Delta \mathrm{X}_{1} \text { does not Granger } \\
\text { Cause } \Delta \mathrm{X}_{17}\end{array}$ & 1.757 & 0.211 & 3.250 & $0.092 *$ & 3.080 & 0.128 & 71.034 & $0.013 * *$ \\
\hline 10 & $\begin{array}{l}\Delta X_{19} \text { does not } \\
\text { Granger Cause } \Delta X_{1}\end{array}$ & 0.002 & 0.966 & 0.627 & 0.558 & 5.941 & $0.042 * *$ & 1.803 & 0.387 \\
\hline 11 & $\begin{array}{l}\Delta X_{1} \text { does not Granger } \\
\text { Cause } \Delta X_{20}\end{array}$ & 12.163 & $0.005 * * *$ & 5.420 & $0.032 * *$ & 7.622 & $0.025 * *$ & 215.198 & $0.004 * * *$ \\
\hline
\end{tabular}

*.**.*** - Significant at 10\%. 5\%. 1\% critical level

Source: Authors' calculations

Therefore, there is unidirectional relationship of cause and effect between derivatives market growth and growth GDP per capita, gross capital formation and Broad money. The impact of derivatives market growth on these indicators is shown only from a lag 4 . 
Between growth of volume of operations in the derivatives market and GDP growth - communication arises in the second and fourth lags; between the annual volume of amounts outstanding of financial derivatives and unemployment rate - in the second and third mastiffs; growth of market sizes the derivative affected personal income since the first lag and lasted throughout the second and third lag; between derivatives market growth and Manufacturing Purchasing Managers Index - in a lag 2; between the annual volume of amounts outstanding of financial derivatives and clean portfolio investment from the first lag; between growth of volumes in the derivatives market and Domestic credit to private sector by banks throughout all lags.

As results of a research positive testify and statistically considerable influence has the annual volume of amounts outstanding of financial derivatives on such indicators: Domestic credit to private sector by banks in lag 2 (F-statistics 12.163, p- value 0.0051***) and 4 (F-statistics 215.198, p- value 0.0046***) and Personal income in lag 1 (F-statistics 10.604, p- value $0.0076^{* * *}$ ) and 2 (F-statistics 10.058 , p- value $0.0066^{* * *}$ ).

Besides, we revealed also other unidirectional relationship of cause and effect. Therefore, bank capital to assets ratio ( F - statistics 5.419, p - value $0.0420 * * *)$ and received personal remittances ( $\mathrm{F}$ - statistics 5.419, p - value $0.0420 * * *)$ influence market growth the derivative in the 3rd manhole. This influence is significant.

These results confirm that growth of the annual volume of amounts outstanding of financial derivatives positively influence on economic growth. At the same time positive impact of the derivatives market on gross capital formation is observed. This indicator is the indicator of long-term development of economic and demonstrates continuous reproductive processes in economy U.S.

The indicator of broad money shows level of development of the financial market and efficiency of monetary policy of the country and certainly the financial market has special value for normal development of economy and is rather difficult both behind structure, and by results of influence on all economic processes. As the sector of the financial market the derivatives market has to have influence on development of financial market, and the financial sector, in turn, pours on economic growth about what lead up ours a research. Similar results were received by Haiss and Sammer (2010), Lazovy and Sipko (2014), Bujari and VenegasMartínez (2016).

Through the size and influence on economy some researchers consider that derivatives should be included in definition of broad money to make monetary policy of the central banks more effective (Savona and Maccario, 1998).

The influence of the derivatives market on unemployment rate is in line with the findings of Lazovy and Sipko (2014), which indicate that growth of OTC market derivatives increases unemployment, for the second lag. In this case, the authors claim a negative correlation between the growth of the outstanding amounts of exchange derivatives and the unemployment rate.

It is interesting that derivatives market growth positively influences on a personal income since the first lag and lasted throughout the second and third lags. As macroeconomic indicator of personal income characterize a condition of purchasing power of the population, system of the distributive relations and prospects of development of economy.

The growth of the annual volume of amounts outstanding of financial derivatives increases Manufacturing Purchasing Managers Index in the second lag which is positive effect as characterizes positive changes of an economic market condition and enterprise confidence in economy that is caused by a hedging derivatives function. Let's notice that positive impact of growth of the derivatives market affected from the first lag on an indicator of net portfolio investment that demonstrates to quick response of an indicator of net portfolio Investment to volumes of operations in the derivatives market that will also be coordinated with growth of broad money.

Let's notice that the research allowed defining positive impact of growth of the derivatives market on Domestic credit to private sector by banks throughout all lags. According to us, such result is caused by success of the derivatives market as institutions that allow it to affect efficiency of the financial market in general. It means what loans and crediting is carried out at the lowest price, than it would be without application financial derivatives as derivatives allow reducing transaction costs (Sill, 1997). It, in turn, leads to acceleration of economic growth (Sill, 1997).

Within the last 40 years the capital markets of the USA grew much quicker, than banks so a part of the bank credits in the private non-financial sector decreased from 55\% to $34 \%$ (Over the past 40 years, U.S. capital markets have grown much faster than banks, so that banks' share of credit to the private nonfinancial sector has dropped from of 55\% to of 34\% (Cecchetti and Schoenholtz, 2018). However, banks remain powerful structure of the financial market and banking system defines stability of the economic environment which surrounds bank. Stability of a banking system is a basis of development of real economy and decision-making 
in the sphere of capital investments. The bank capital to assets ratio indicator allows estimating financial stability of banks. Banks actively use financial derivatives and have considerable volumes of operations with them as derivatives are the effective instrument of hedging of market risks. Therefore, according to us, influence of the banking sector on derivatives market growth is natural.

During the research was found that the indicator of received personal remittances positively influences on derivatives market growth. The indicator of received personal remittances is independent and rather essential indicator of development of economy and a separate segment of the financial market, which dynamically develops, and can be a source of investments for opening and development of small business. We consider this conclusion important. It needs further researches to check and explain this influence.

\section{Conclusions}

Derivatives have become a common instruments for a wide range of users, including financial institutions, companies that manage assets, corporations, hedge funds. These instruments allow for speculative, arbitrage and hedging operations, which defines them as a useful instruments to stimulate the growth of the efficiency of financial markets and the real economy.

The modern derivatives market is as "adapter" for the integration of markets. They allow the resource and financial risk among national systems with different institutional structure and sizes (Haiss and Sammer, 2010).

Nowadays the financial derivatives market is the largest segment of the financial market. The growth of organized derivatives market is a sign that flow of funds are aggregated by derivatives market from the real economy and through the function of "transfer of economic resources in time over geographic regions and among industries (Haiss and Sammer, 2010) effectively allocate and deployment hem. This is what we consider has an influence on economic growth.

Characteristic signs of the derivatives market are forming a role, interrelations and define the allocated place and specifics of influence of this segment of the financial market on other markets. At the same time derivatives market belongs to the post-industrial level of society development, tertiary to the sector of economy and to the fictitious capital II and III about that became a basis of their use not only for the purpose of risk management, but also in more large-scale speculative operations. Therefore this segment of the financial market began to separate promptly from the real capital and had an opportunity of independent existence.

The most common exchange contracts are futures and options. Their success is primarily due to high liquidity, guarantee of payment and leverage effect. The interaction between real capital and the derivatives market now depends of financial indices, ratings, quotations, level of capitalization and other financial information.

Derivatives influence on different sectors of the financial market can be a miscellaneous, but all sectors react better and quicker in the presence of the market of derivative tools.

This article seeks to confirm the hypothesis of the causal link between the activities of the organized derivatives market on growth of real economic. To prove it, we considered a set of variables from 21 macroeconomic and financial indicators. The empirical analysis is limited to one country the United States and covers the period from 2000 to 2015.

This article contributes into the scientific literature is to substantiate and confirm the hypothesis about the impact of the exchange-traded derivatives market on growth of economic. Granger causality test allowed revealing the cause-and-effect relations of the organized derivatives market with economic growth in the United States. In this article is used a large amount of statistical data of time series and variables of macroeconomic and financial indices. The results obtained during the study can be used to substantiate the necessary measures aimed on the development of the derivatives market in Ukraine.

Using Granger causality test we study the influence of organized derivatives market on economic growth during the period 2000-2015. The study allowed getting the results with the following conclusions:

1. Positive and statistically considerable influence has the annual volume of amounts outstanding of financial derivatives on such indicators: Domestic credit to private sector by banks in lag 2 (F-statistics 12.163, p- value 0.0051) and 4 (F-statistics 215.198, p- value 0.0046) and Personal income in lag 1 (Fstatistics 10.604, p- value 0.0076) and 2 (F-statistics 10.058, p- value 0.0066).

2. Results confirm that the growth of the annual volume of amounts outstanding of financial derivatives positively influences on economic growth, especially on indicators $\Delta \mathrm{X}_{3}$ - growth GDP per capita (F-statistics 
$0.0370^{* *}, \mathrm{p}$-value $0.0370^{* *}$ ) in lag 4 and $\Delta \mathrm{X}_{4}-$ GDP growth (F-statistics 33.546 , p-value $0.0292^{* *}$ ) also in $\operatorname{lag} 4$.

3. Derivatives market growth positively influences on increase in personal income since the first lag and lasted throughout the second and third lags.

4. Derivatives market development influences on rise in unemployment in the second and third lags that, according to us, is contradictory with the revealed positive impact of the derivatives market on personal income that needs further researches.

5. Positive impact of development of the derivatives market on domestic credit to private sector by banks throughout all lags is observed.

6. The research allowed to reveal us and other type of influence. Therefore, Bank capital to assets ratio (F-statistics 5.419, p- value 0.0420***) and received personal remittances (F-statistics 5.419, p- value $0.0420 * * *)$ influence on increase of derivatives market in the $3^{\text {rd }}$ lag. This influence is significant.

7. During the research was also founded that the indicator of received personal remittances positively influences on derivatives market growth. The indicator of received personal remittances is independent and rather essential indicator of development of economy and a separate segment of the financial market which dynamically develops, and can be a source of investments for opening and development of small business. We consider this conclusion is important. It needs further researches to check and explain this influence.

\section{References}

[1] M. Arena, "Does Insurance Market Activity Promote Economic Growth? A Cross-Country Study for Industrialized and Developing Countries", The Journal of Risk and Insurance, vol.75(4), pp. 921-946, 2008.

[2] A. Baluch and M. Ariff, "Derivative markets and economic growth: Is there a relationship? ", Working Paper Series, pp.1-45, 13, November 2007.

[3] A. Bujari and A.Venegas-Martínez "Impact of derivatives markets on economic growth in some of the major world economies: A difference-GMM panel data estimation (2002-2014) ", The IEB International Journal of Finance, vol.12, pp.110-127, 2016.

[4] G. Stephen Cecchetti and L. Kermit Schoenholtz, "Understanding Bank Capital: A Primer", Money and Banking. URL: https://www.moneyandbanking.com/commentary/2018/2/11/understanding-bankcapital-a-primer, 2018.

[5] Eleventh Meeting of the IMF Committee on Balance of Payments Statistics Washington, D.C., October 21-23, 1998. URL: https://www.imf.org/external/bopage/pdf/ 98-1-20.pdf.

[6] G.Favara, "An Empirical Reassessment of the Relationship between Finance and Growth", Working Paper, 03/123, pp.1-46, 2009.

[7] J.Greenwood and B. Jovanovic, "Financial Development, Growth and the Distribution of Income". Journal of Political Economy, vol.98(5), pp.1076-1107, 1990.

[8] J. Gurley and E.Shaw, "Financial Structure and Economic Development", Economic Development and CulturalChange, vol.15, pp.257-268, 1967.

[9] Peter R. Haiss and B. Sammer, "The Impact of Derivatives Markets on Financial Integration, Risk, and Economic Growth", Conference proceedings of the 10th Biennial Conference on Regulatory Responses to the Financial Crisis.Conducted by the Bundesbank /Athenian Policy Forum. Frankfurt: the Bundesbank/Athenian Policy Forum, 2010.

[10] J. Hicks, "A theory of economic history", Oxford University Press, Oxford, 1969.

[11] International Financial Reporting Standard 9, Financial Instruments (IFRS 9) URL: https://www.ifrs.org/issued-standards/list-of-standards/ifrs-9-financial-instruments/

[12] R. King and R. Levine, "Finance and Growth: Schumpeter might be right", The Quarterly Journal of Economics, vol.108, pp.717-737, 1993.

[13] J. Lazovy and J. Sipko, "Impact of Financial Derivatives on the Real Economy", International Journal of Management Excellence, vol.4(1), pp.494-502, 2014. 
[14] R. Levine and S. Zervos, "Stock Markets, Banks, and Economic Growth", The American Economic Review, vol.88(3), pp.537-558, 1998.

[15] R. Merton, "Financial Innovation and Economic Performance", Journal of Applied Corporate Finance, vol. 4(4), pp.12-22, 1992.

[16] R. Merton, "Financial innovation and the management and regulation of financial institutions", Journal of Banking and Finance, vol.19(3/4), pp. 461-481, 1995.

[17] R. Merton and Z. Bodie, "Design of Financial Systems: Towards a Synthesis of Function and Structure", Journal of Investment Management, vol.3(1), pp.1-23, 2005.

[18] V. Oliinyk, "Optimal Management of GDP Components", Journal of Advanced Research in Law and Economics, vol. IX, 2(32), pp. 603-614, 2018.

[19] R. Rajan, "Has Financial Development Made the World Riskier?", European Financial Management, vol.12(4), pp.499-533, 2006.

[20] Paul M. Romer, "Increasing Returns and Long-Run Growth", The Journal of Political Economy, vol. 94(5), pp.1002-1037, 1986.

[21] P. Rousseau and P. Wachtel, "What is happening to the impact of financial deepening on economic growth?", Working Paper, 09-W15, Department of Economics Vanderbilt University Nashville, , pp.1-25, September 2009.

[22] P. Savona and A. Maccario, "On the Relation between Money and Derivatives and its Application to the International Monetary Market", Open economies review, vol.9, pp. 637-664, 1998.

[23] R. Solow, "A Contribution to the Theory of Economic Growth", The Quarterly Journal of Economics, vol.70(1), pp.65-94, 1956.

[24] V., Babenko, I., Perevozova, O., Mandych, T., Kvyatko, O., Maliy, I., Mykolenko, "World informatization in conditions of international globalization: factors of influence", Global. J. Environ. Sci. Manage., 5(SI): 172-179, 2019. DOI: 10.22034/gjesm.2019.SI.19

[25] K. Sill, "The Economic Benefits and Risks Of Derivative Securities Business", Business Review, Federal Reserve Bank of Philadelphia, pp.15- 26, issue Jan 1997.

[26] V., Babenko, O., Nazarenko, I., Nazarenko, O., Mandych, “Aspects of program control over technological innovations with consideration of risks", Eastern-European Journal of Enterprise Technologies, Vol. 3/4 (93), pp. 6-14, 2018. DOI: 10.15587/1729-4061.2018.133603

[27] G.Tsetsekos and P.Varangis, "Lessons in Structuring Derivatives Exchanges", The World Bank Research Observer, vol.15(1), pp.85-98, 2000. 